\title{
UJI KUALITAS BAKASANG IKAN CAKALANG (KATSUWONUS PELAMIS) YANG ADA DI PASARAN BERDASARKAN PARAMETER FREE FATTY ACID (FFA) DAN PEROXIDE VALUE (PV)
}

\author{
Gisella T. Montolalu ${ }^{1 *}$, Feti Fatimah ${ }^{1}$ dan Vanda S. Kamu ${ }^{1}$ \\ ${ }^{1}$ Jurusan Kimia Fakultas Matematika dan Ilmu Pengetahuan Alam Universitas Sam Ratulangi, \\ Jl. Kampus Unsrat, Kleak, Manado 95115 Sulawesi Utara
}

\begin{abstract}
ABSTRAK
Bakasang adalah produk fermentasi yang dibuat dari jeroan ikan. Telah dilakukan penelitian uji kualitas bakasang ikan cakalang (Katsuwonus pelamis) yang ada di pasaran berdasarkan parameter Free Fatty Acid (FFA) dan Peroxide value (PV). Bakasang yang digunakkan berasal dari empat tempat berbeda Sario, Tambala, Supermarket dan Karombasan. Bilangan peroksida tertinggi adalah bakasang yang dibeli di Supermarket $5,18 \mathrm{meq} / \mathrm{kg}$ dan yang terendah adalah bakasang yang dibeli di Tambala $3,88 \mathrm{meq} / \mathrm{kg}$. Asam lemak bebas tertinggi adalah bakasang yang dibeli di Karombasan 2,13\% dan yang terendah adalah bakasang yang dibeli di Sario 1,25\%.
\end{abstract}

Kata kunci: Kualitas bakasang, ikan cakalang, free fatty acid, peroxide value

\begin{abstract}
Bakasang is a fermented product made from fish innard. Research has been conducted of the quality of cakalang fish (Katsuwonus pelamis) on the market has been conducted based on the parameters of Free Fatty Acid (FFA) and Peroxide value (PV). Bakasang used are from four different places: Sario, Tambala, Supermarket and Karombasan. The highest peroxide number was bakasang purchased at $5.18 \mathrm{meq} / \mathrm{kg}$ Supermarket and the lowest was bakasang purchased at Tambala $3.88 \mathrm{meq} / \mathrm{kg}$. The highest free fatty acid was bakasang which was bought in Karombasan $2.13 \%$ and the lowest was bakasang which was bought in Sario $1.25 \%$.
\end{abstract}

Keywords: Quality of bakasang, cakalang fish, free fatty acid, peroxide value

\section{PENDAHULUAN}

Indonesia memiliki sumber daya hayati laut yang sangat besar dengan kandungan berbagai macam jenis makhluk hidup di dalamnya. Salah satu jenis ikan yang banyak terdapat di Sulawesi Utara adalah ikan cakalang. Ikan jenis ini banyak diolah oleh masyarakat dengan memanfaatkan dagingnya sebagai buah tangan tradisional seperti abon dan cakalang fufu, sedangkan sebagian kecil masyarakat mengolah isi perut (jeroan) ikan cakalang menjadi bakasang.

Bakasang adalah saus ikan fermentasi yang terbuat dari jeroan berbagai ikan. Ini adalah makanan khas Sulawesi Utara. Saus ikan adalah cairan coklat jernih hingga kemerahan dengan rasa asin dan rasa ikan yang khas. Proses fermentasi umumnya memakan waktu tidak kurang dari 6 bulan. Cairan tersebut diperoleh dari hidrolisis fermentasi alami ikan. Selain bertujuan untuk pengawetan, makanan fermentasi juga memiliki manfaat tambahan, seperti meningkatkan rasa, meningkatkan daya cerna, dan meningkatkan nilai terapeutik. Produk ini juga mengandung bakteri asam laktat dengan sifat antimikroba (Fatimah dkk., 2017).

Anihouvi dkk. (2006) menyatakan bahwa umumnya produk ikan fermentasi diproses secara spontan dan proses fermentasi berjalan tidak terkendali. Ini mengakibatkan beragam kualitas produk dan produk tersebut rentan terhadap kerusakan. Kakati dan Goswani (2013) menyatakan bahwa produk ikan fermentasi sebagian besar diproduksi di rumah tangga atau industri kecil dengan kontrol kualitas dan keamanan produk yang terbatas. Prosedur yang digunakan untuk pemrosesan produk ikan fermentasi seringkali tidak disertai dengan pemasakan atau pasteurisasi untuk menghancurkan patogen. Produk disimpan dalam suhu kamar dan penggunaan konsentrasi rendah garam atau bebas garam sehingga sangat rentan terhadap risiko mikrobiologi yang tinggi. Penelitian ini bertujuan untuk menentukkan perbedaan kualitas bakasang ikan cakalang (Katsuwonus pelamis) yang ada di pasaran 
berdasarkan parameter proksimat, Free Fatty Acid (FFA) dan Peroxide value (PV).

\section{BAHAN DAN METODE}

\section{Bahan dan alat}

Bahan yang digunakan adalah bakasang ikan cakalang (Katsuwonus pelamis) yang diambil di pasaran dari 4 tempat yang berbeda: 1 . Supermarket, 2. Karombasan, 3. Sario, 4. Tambala, aquades, kloroform, asam asetat glasial, larutan jenuh kalium iodida, natrium tiosulfat $\left(\mathrm{Na}_{2} \mathrm{~S}_{2} \mathrm{O}_{3}\right)$, etanol $95 \%$, indikator amilum, indicator $\mathrm{PP}$, dan natrium hidroksida $(\mathrm{NaOH})$. Alat yang digunakan adalah buret, wadah untuk sampel, sudip, erlenmeyer, gelas ukur, gelas piala, pipet tetes.

\section{Uji free fatty acid (FFA)}

Ditimbang $14 \mathrm{~g}$ bakasang ikan cakalang dan dimasukkan ke dalam Erlenmeyer $250 \mathrm{~mL}$, selanjutnya ditambahkan $25 \mathrm{~mL}$ etanol $95 \%$ dan dipanaskan pada suhu $40^{\circ} \mathrm{C}$ setelah itu ditambahkan $2 \mathrm{~mL}$ indikator PP, dilakukan titrasi dengan larutan $0,05 \mathrm{M} \mathrm{NaOH}$ sampai berwarna merah jambu dan tidak hilang selama 30 detik.

$\% \mathrm{FFA}=\frac{(\mathrm{mL} \mathrm{NaOH} \times \mathrm{M} \mathrm{NaOH} \times \mathrm{BM})}{(\text { berat sampel } \times 1000)} \times 100 \%$

Keterangan: \% FFA: Kadar asam lemak bebas, mL NaOH: Volume titrasi $\mathrm{NaOH}, \mathrm{M} \mathrm{NaOH}$ : Molaritas larutan $\mathrm{NaOH}$ (mol/L), BM: Berat molekul asam lemak (asam lemak palmitat) 256 $\mathrm{g} / \mathrm{mol}$.

\section{Uji peroxide value (PV)}

Sebanyak $10 \mathrm{~g}$ sampel dimasukkan ke dalam Erlenmeyer tertutup dan ditambahkan $30 \mathrm{~mL}$ pelarut campuran asam asetat glasial: kloroform $(3: 2 \mathrm{v} / \mathrm{v})$. Setelah bakasang larut sempurna ditambahkan 0,5 mL larutan Kalium Iodida jenuh dan dibiarkan 1 menit sambil dikocok, kemudian ditambahkan $30 \mathrm{~mL}$ aquades. Iodium yang dibebaskan oleh peroksida dititrasi dengan larutan standar natrium tiosulfat $\left(\mathrm{Na}_{2} \mathrm{~S}_{2} \mathrm{O}_{3}\right) \quad 0,1015 \mathrm{~N}$ dengan indikator amilum sampai warna biru hilang. Bilangan peroksida dinyatakan dengan rumus perhitungan sebagai berikut:

Bilangan peroksida $=\frac{((S-B) \times N \times 1000)}{\left.\left(\frac{(\text { meq peroksida })}{(\text { kg fat })}\right) \text { berat sampel }(g)\right)}$

Keterangan: $\mathrm{S}=$ titrasi sampel, $\mathrm{B}=$ titrasi blanko, $\mathrm{N}=$ Normalitas $\mathrm{Na}_{2} \mathrm{~S}_{2} \mathrm{O}_{3}$

\section{HASIL DAN PEMBAHASAN}

Free fatty acid (FFA)

Menurut Khoddami dkk. (2009), semakin tinggi suhu maka pembentukan radikal bebas dan asam lemak bebas akan semakin cepat. Dapat disimpulkan bahwa semakin tinggi suhu dan waktu penyimpanan pada pengolahan bakasang ikan cakalang menyebabkan semakin tinggi pula kadar asam lemak bebas yang didapatkan sehingga bisa mempengaruhi kualitas dari bakasang. Berdasarkan standar yang ditetapkan dalam IFOMA (1998), kandungan asam lemak bebas pada minyak ikan kasar yang baik adalah 1-7\%, namun dalam industri tertentu standar kandungan asam lemak bebas yang digunakan adalah 2-5\% .

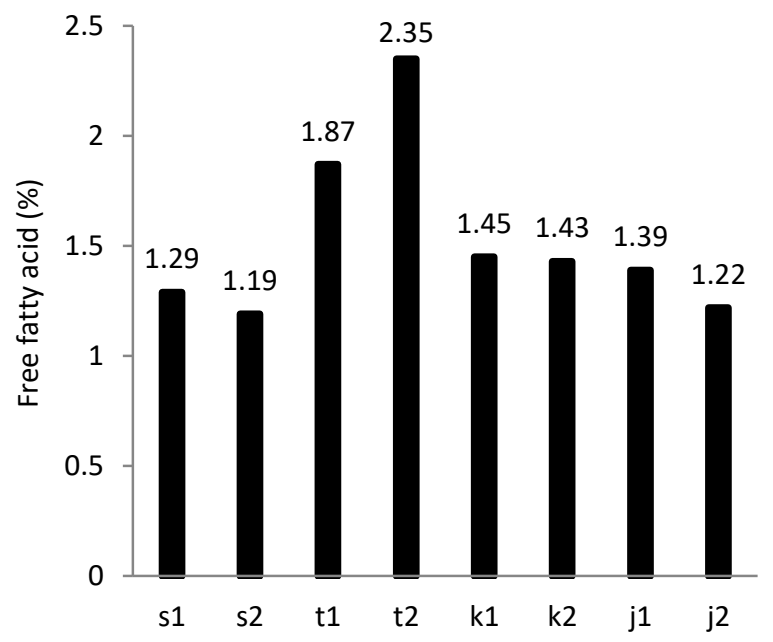

Gambar 1. Nilai FFA bakasang ikan cakalang. Keterangan J: supermarket, K: Tambala, S: Sario, T: Karombasan.

Gambar 1 menunjukkan bahwa kadar asam lemak bebas paling tinggi sampel bakasang T2 yaitu 2,35\% sedangkan untuk kadar asam lemak bebas paling rendah sampel bakasang S2 yaitu $1,19 \%$. Berdasarkan hasil penelitian tersebut dan hasil pengujian bakasang ikan cakalang (Mongdong dkk., 2019) Lama penyimpanan umumnya dapat merusak lemak dengan menghasilkan cita rasa tidak enak (Ketaren, 2005). Penyimpanan yang salah dalam jangka waktu tertentu dapat menyebabkan pecahnya ikatan trigliserida pada minyak lalu membentuk gliserol dan asam lemak bebas (Sutiah dkk., 2008).

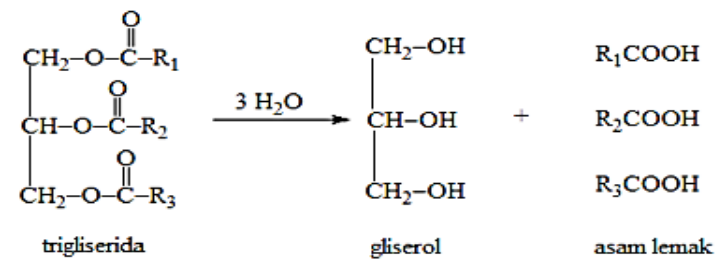

Gambar 2. Reaksi pembentukan asam lemak bebas 


\section{Peroxide value $(\mathrm{PV})$}

Bilangan peroksida merupakan bilangan yang menentukan derajat kerusakan pada minyak. Minyak yang mengandung asam lemak tak jenuh dapat mengikat oksigen sehingga membentuk peroksida (Ginanjar dkk., 2015). Menurut Sri Raharjo (2004) Dari beberapa publikasi sering dilaporkan bahwa garam yang ditambahkan pada daging menyebabkan perubahan warna dan ketengikan. Semula garam diduga mengkatalisa oksidasi melalui aktifitas lipoksidase. Menurut International Fishmealand Oil Manufactures Association (IFOMA) standar angka peroksida yaitu 3-25 meq/kg sampel.

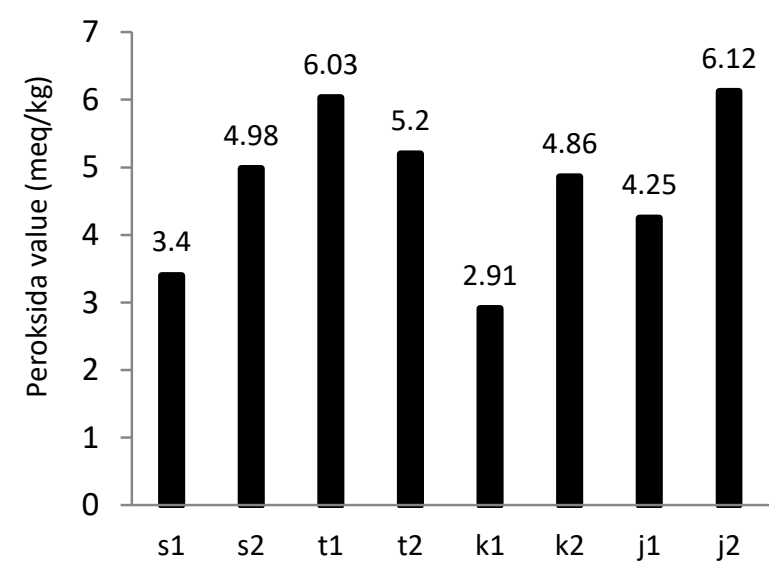

Gambar 3. Nilai PV bakasang ikan cakalang. Keterangan: J (supermarket), K (Tambala), S (Sario), T (Karombasan)

Berdasarkan gambar 3 menunjukkan nilai bilangan peroksida yang tertinggi terdapat pada sampel J2 6,12\% yang dibeli di Supermarket dan yang terendah adalah sampel bakasang K1 2,91\% yang dibeli di Tambala, hal ini menunjukkan bahwa semakin tinggi suhu dan lama fermentasi, semakin besar nilai peroksida.

$$
\begin{gathered}
\mathrm{R}-\mathrm{COOH}+2 \mathrm{KI}+\mathrm{H}_{2} \mathrm{O} \rightarrow \mathrm{R}-\mathrm{OH}+\mathrm{I}_{2}+\mathrm{KOH} \\
\mathrm{I}_{2}+2 \mathrm{Na}_{2} \mathrm{~S}_{2} \mathrm{O}_{3} \rightarrow 2 \mathrm{NaI}+\mathrm{Na}_{2} \mathrm{~S}_{4} \mathrm{O}_{6}
\end{gathered}
$$

Gambar 4. Reaksi pembentukan bilangan peroksida

Hal ini didukung oleh pendapat Winarno (1992), bahwa reaksi oksidasi minyak dimulai dengan pembentukan radikal-radikal bebas yang disebabkan oleh faktor-faktor yang dapat mempercepat reaksi seperti cahaya, energi panas, katalis logam dan enzim. Radikal bebas dengan oksigen akan membentuk peroksida aktif yang dapat membentuk hidroperoksida yang bersifat sangat tidak stabil.

\section{KESIMPULAN}

Berdasarkan hasil penelitian kualitas bakasang ikan cakalang (katsuwonus pelamis) sebagai berikut, Kadar Peroxide value (PV) tertinggi adalah bakasang yang dibeli di Supermarket dan yang terendah dibeli di Tambala. Kadar Free Fatty Acid (FFA) tertinggi adalah bakasang yang dibeli di Karombasan dan yang terendah dibeli di Sario.

\section{DAFTAR PUSTAKA}

Anihouvi, V.B., Ayernor, G.S., Hounhouigan, J. D. \& Sakyi-Dawson, E. 2006. Quality characteristics of Lanhouvin: A traditionally processed fermented fish product in the republic of Benin. African Journal of Food Agriculture Nutrition Development. 6, 1-15.

Fatimah, F, Pelealu, J.J., Gugule, S., Yempormase, H. V. \& Tallei, T.E. 2017. Quality evaluation of bakasang processed with variation of salt concentration, temperature and fermentation time. Pakistan Journal of Biological Sciences. 20(11), 543-551.

Ginanjar, G.R., Maulana, I.T. \& Kodir, R.A. 2015. Ekstraksi minyak dari kijing (Pilsbryoconcha exilis lea) serta analisis kandungan asam lemak menggunakan $\mathrm{Kg}$ Sm. Prosiding. 79-85.

Kakati, B.K., \& Goswami, U.C. 2013. Characterization of the traditional fermented fish product shidol of Northeast India prepared from Puntius sophore and Setipinna phasa. Indian Journal of Traditional Knowledge. 12(1), 85-90.

Khoddami, A., Arifin, A.A., Bakar, J. \& Ghazali, H.M. 2009. Fatty acid profile of the oil exstracted from fish waste (head, intestine, liver) Sardinella lemuru. Journal of World Applied Sciences. 7(1), 127-131.

IFOMA. 1998. International Fishmeal and Oil Manufacturers Association. United Kingdom: Hertfordshire.

Mongdong, A.G., Fatimah. F., \& Rorong. J. 2019. Umur simpan bakasang ikan cakalang (Katsuwonus pelamis) dengan metode Accelerated Shelft Life Test (ASLT) berdasarkan parameter Free Fatty Acid (FFA). Pharmacon. 8(3), 252-257.

Sutiah, K. S., Firdausi, W. \& Budi, S. 2008. Studi kualitas minyak goreng dengan parameter 
48 Chem. Prog. Vol. 12. No. 1, Mei 2019

viskositas dan indeks bias. Jurnal Fisika. Winarno, F.G. 1992. Kimia pangan dan gizi. 11(2), 53-58.

Jakarta: Gramedia Pustaka Utama. 